\title{
PAHAM KEAGAMAAN DOSEN PAI UNIVERSITAS PASUNDAN BANDUNG
}

\author{
Suprapto \\ Peneliti Puslitbang Pendidikan Agama dan Keagamaan \\ Jl. M.H. Thamrin No. 6 Jakarta Pusat \\ Puslitbangpenda@yahoo.co.id
}

\begin{abstract}
Religious understanding of Islamic studies lecturers in Pasundan University Bandung in this study is related to the relation between religion and state, relation between religion and tolerance, relation between religion and human rights, and relation between religion and gender equality. The findings include that the state should be involved in religious affairs in order to create order to avoid disharmony in inter-religious relations. The state has the authority to conduct enforcement in case of problems related to inter-religious relations. The conception of human rights in Islam is balance between rights and obligations. With regard to gender equality, there is a tendency that leadership in politics or government must be held by men, not women because men are destined to become the leader on earth. Nevertheless, the informants believe that women can be made leaders if there is no man who is able to become a leader.
\end{abstract}

Keywords: religious understanding, Islamic studies lecturer

\section{Abstrak}

Paham keagamaan dosen PAI di Universitas Pasundan (Unpas) Bandung dalam penelitian ini terkait dengan relasi agama dan negara, relasi agama dan toleransi, relasi agama dan HAM, seta relasi agama dan kesetaraan jender. Temuannya antara lain, bahwa negara harus terlibat dalam urusan agama dalam rangka menciptakan ketertiban agar tidak terjadi disharmoni dalam hubungan antar umat beragama. Negara memiliki otoritas untuk melakukan penertiban bila terjadi persoalan terkait dengan hubungan antar umat beragama. Konsepsi HAM dalam Islam yakni menyeimbangkan antara hak dan kewajiban. Terkait dengan kesetaraan gender, terlihat adanya kecenderungan pandangan bahwa kepemimpinan dalam politik ataupun pemerintahan harus dipegang oleh laki-laki, bukan perempuan. Karena laki-laki ditakdirkan untuk menjadi pemimpin di muka bumi. Meskipun demikian, dalam pandangan informan seorang perempuan boleh saja manjadi pemimpin jika memang tidak ada laki-laki yang mampu untuk menjadi pemimpin.

Kata Kunci: paham keagamaan, dosen PAI

\section{PENDAHULUAN}

Pendidikan Agama di Perguruan Tinggi Umum (PTU) dalam bentuk Mata Kuliah Agama, menurut SK Mendiknas No.232/U/2000 dan No.45/U/2002, tidak masuk dalam materi tersendiri, akan tetapi masuk dalam materi Mata Kuliah Pengembangan Kepribadian
(MPK). Pendekatan baru dalam proses pembelajaran sudah mengalami restrukturisasi menggunakan model Kurikulum Berbasis Kompetensi (KBK), dimana materi pengajaran keagamaan lebih mengedepankan aspek kompetensi tertentu ketimbang sebuah pengetahuan dan pemahaman yang lebih baik. 
PP No. 55 tahun 2007 pada pasal 1 ayat 1 ketentuan umum bahwa yang dimaksudkan dengan pendidikan agama adalah sebuah pendidikan yang memberikan pengetahuan dan membentuk sikap, kepribadian dan keterampilan peserta didik dalam mengamalkan ajaran agamanya yang dilaksanakan sekurang kurangnya melalui mata pelajaran / kuliah pada semua jalur, jenjang dan jenis pendidikan. Hal ini berarti bahwa pendidikan agama merupakan mata kuliah tersendiri, tidak digabungkan dengan mata pelajaran/ mata kuliah lainnya pada semua jenjang pendidikan, termasuk pada bangku kuliah. Adapun fungsi dari pendidikan agama sendiri dalam pasal 2 ayat 1 PP No 55 tahun 2007 adalah membentuk manusia Indonesia yang beriman bertakwa kepada Tuhan Yang Maha Esa, serta berakhlak mulia dan mampu menjaga kedamaian dan kerukunan hubungan inter dan antar umat beragama. Sedangkan dalam pasal 2 ayat 2, Pendidikan agama juga bertujuan untuk berkembangnya kemampuan peserta didik dalam memahami, menghayati, dan mengamalkan nilai nilai agama yang menyerasikan penguasaannya dalam pengembangan ilmu pengetahuan, seni dan teknologi. Dan penanggung jawab pendidikan agama (dalam semu jenjang pendidikan adalah Menteri Agama (Pasal 3 ayat 2).

Dalam SK No.43/DIKTI/Kep. 2006 tercantum rambu-rambu pelaksanaan MPK ini di Perguruan Tinggi, khususnya rumusan visi, misi, standar kompetensi, dan kompetensi dasar. Visi dan misi MPK memberi penekanan kepada pemantapan kepribadian mahasiswa sebagai manusia Indonesia seutuhnya, yang secara konsisten mampu mewujudkan nilainilai dasar keagamaan dan kebudayaan. Kompetensi dasar Pendidikan Agama adalah menjadi ilmuwan; (i) profesional, (ii) beriman dan bertaqwa kepada Tuhan Yang Maha Esa, (iii) berakhlak mulia, (iv) memiliki etos kerja, (v) berkepribadian dewasa, menjunjung tinggi nilai-nilai kemanusiaan dan kehidupan. Hal ini berarti perbedaan teologis dan perbedaan madzhab dalam masalah fiqihiyah tidak menjadi materi utama dalam pendidikan keagamaan di Pendidikan Tinggi Umum (PTU).

Namun demikian, dalam implementasinya, kompetensi yang ingin dicapai dalam pendidikan agama tersebut, sulit untuk terealisasi. Ada beberapa hal yang menyebabkan tidak tercapainya kompetensi tersebut, antara lain; (a) sedikitnya jumlah sks untuk mata kuliah agama yang diberikan kepada mahasiswa, dan biasanya dilakuan pada semester awal masuk kuliah, (b) model dan sistem pembelajaran mata kuliah agama yang lebih cenderung dogmatif dan tidak kritis. Pendidikan keagamaan lebih bersifat monolog doktriner, tidak ada perdebatan dan adu gagasan.(c) materi kuliah keagamaan yang tidak memadai, (d) dosen yang tidak kompeten dan profesional. Akibatnya para mahasiswa banyak mencari dan mendapatkan pemahaman keagamaan diluar kampus. Mereka memperoleh pengetahuan dan pemahaman keagamaan dari kelompok kelompok kajian keislaman, seperti kelompok kelompok halaqah/usrah atau kelompok studi ke-Islaman kampus yang formal seperti Lembaga Dakwah Kampus (LDK). ${ }^{1}$

Selain yang formal, ada juga kelompokkelompok kajian Islam yang lebih informal dan bersifat underground, seperti Jama'ah Tabligh, Tarbiyah, Hizbut Tahrir, Ikhwanul Muslimin, Salafi dan lainnya. Kelompok kelompok kajian Islam tersebut menawarkan banyak warna dan pendekatan dalam pemahaman ke-Islam-an, mulai yang tekstualis normatif, hingga yang kontekstualis liberal. Perbedaan pendekatan dalam pemahaman ke-Islam-an

1 Beberapa Lembaga Dakwah Kampus dapat disebutkan di sini: di IPB dan Untan ada Badan Kerohanian Islam Mahasiswa (BKIM), di Universitas Hasanuddin (Unhas) ada MPM (Mahasiswa Pecinta Musholla), di Universitas Negeri Solo (UNS) ada Lembaga Dakwah Kampus (LDK), di Universitas Brawijaya (Unbraw) ada Unit Akitifitas Kerohanian Islam (UAKI), Universitas Andalas (Unand) ada Forum Kajian Islam (FKI), Jama'ah Salahuddin di UGM, Jama'ah Masjid Salman di ITB, Jama'ah Manarul Ilmi di ITS, Salam di UI dan lainnya. 
yang mengakibatkan munculnya kelompokkelompok keagamaan di kampus mulai yang radikal ekstrim, fundamental, moderat, dan liberal. Perbedaan pendekatan tersebut juga menghasilkan perbedaan dalam aksiaksi keberagamaan. Fenomena munculnya radikalisme, fundamentalisme bahkan aksi terorisme di kalangan sebagian mahasiswa, merupakan bentuk kegagalan pendidikan agama di kampus. Penangkapan Pepi Fernando, mahasiswa UIN Syarif Hidayatullah dan Miko Yoshiko, alumni Universitas Jember (UNEJ) oleh Densus 88 terkait aksi terorisme, membuktikan bahwa kampus sebagai menara gading intelektual yang selalu berpikir kritis, tidak bebas dari pengaruh radikalisme dan aksi terorisme.

Melihat hal di atas, dipandang penting untuk dilakukan penelitian terkait dengan paham keagamaan dosen mata kuliah Pendidikan Agama Islam Universitas Pasundan (Unpas) Bandung. Penelitian difokuskan pada 3 (tiga) isu strategis: pertama, faham keagamaan dosen mata kuliah agama di Unpas terkait masalah relasi antara agama dengan negara, toleransi, kesetaraan gender, dan Hak Asasi Manusia (HAM). Kedua, mekanisme dan sistem rekrutmen dosen agama di Unpas. Dan ketiga, proses pendidikan mata kuliah agama Islam di Unpas yang dilihat dari segi kurikulum, sistem pembelajaran, sarana/fasilitas, sumber belajar dan evaluasi belajar

Tujuan penelitin adalah: pertama, menganalisa faham keagamaan para dosen pengajar mata kuliah agama di Unpas terkait masalah relasi antara agama dengan negara, toleransi, kesetaraan gender, dan Hak Asasi Manusia (HAM). Kedua, menganalisa mekanisme dan sistem rekrutmen dosen agama di Unpas. Ketiga, menganalisa proses pendidikan mata kuliah agama di Unpas dari segi kurikulum, sistem pembelajaran, sarana/fasilitas, sumber belajar dan evaluasi belajar.

\section{Kerangka Konseptual}

\section{Konsep dan dimensi keberagamaan}

Agama merupakan dimensi kebutuhan hingga kini bahkan ditempatkan sebagai intitusi kultural yang sentral oleh masyarakat. Agama dikonsepsikan sebagai sistem kepercayaan dan praktek dimana suatu masyarakat atau kelompok berjaga-jaga menghadapi berbagai persoalan. Agama merupakan seperangkat jawaban koheren atas dilema keradaan manusia sehingga menjadikan kehidupan yang lebih bermakna.

Menurut Glock and Stark, terdapat 5 (lima) dimensi keberagamaan, yaitu: keyakinan, praktek agama, pengalaman, pengetahuan dan dimensi konsekuensi. ${ }^{2}$ Dimensi keyakinan diindikasikan dengan berpegang teguh pada pandangan teologis tertentu dan mengakui kebenaran doktrin-doktrin teologis tersebut. Dimensi praktik agama diindikasikan dengan mengerjakan atau adanya perilaku ritual dan ketaatan terhadap agama yang dianut. Dimensi pengalaman dindikasikan dengan perasaanperasaan atau persepsi-persepsi yang dialami yang mengkomunikasikan esensi ketuhanan. Dimensi pengetahuan, diindikasikan dengan pengetahuan mengenai dasar-dasar keyakinan. Dimensi konskuensi, diindikasikan sebagai akibat dari keyakinan kegamaan, praktik, pengalaman dan pengetauan seseorang dalam bentuk pengamalannya dalam kehidupan sehari-hari. Sementara Benda dan Corwyn, untuk mengukur keberagamaan seseorang dapat dilakukan melalui: 1) kehadiran ke tempat ibadah (chruirch attendence), 2) waktu beribadah (time is prayer), 3) mempelajari kitab suci (study the bible/holy book), 4) aktivitas di tempat ibadah (study in chruch), 5) keterlibatan/ kontribusi keuangan (financial contribution), 6) menikmati kehidupan beragama (share joy and problem of relegion life), 7) membicarakan masalah-masalah agama dalam keluarga atau

\footnotetext{
2 Bafadal AR Fadhal. 2005. Pengalaman Agama di Kalangan Pemuda, Jakarta, Sekjen Departemen Agama RI, hal.10
} 
dengan teman-teman (talk about relegion with family and friends) dan 8) mencoba untuk memeluk agama beribadah (try to convert some one).

Emile Durkheim merumuskan setiap agama, terutama agama wahyu, memiliki tiga dimensi dasar keberagamaan (religiousitas). ${ }^{3}$ Pertama, adalah keyakinan beragama (religious belief) yang disebut pula sebagai dimensi idiologis (ideological dimension). Dimensi ini berkaitan dengan pengakuan dan penerimaan terhadap sesuatu atau dzat " yang sakral", "Yang Maha Besar" sebagai suatu kebenaran, atau suatu kenyataan. Keyakinan beragama, meliputi dua aspek yaitu nilai relijius (religious values) dan kosmologi (cosmologi). Nilai relijius berkaitan dengan konsepsi tentang apa yang dipersepsi sebagai sesuatu " yang baik atau buruk", "yang pantas dan tidak pantas", "yang benar dan yang salah"”yang tepat dan tidak tepat" menurut keyakinannya. Nilai relijius dapat membentuk perilaku seseorang dalam kehidupan sosialnya. Sedangkan kosmologi berkaitan dengan penerimaan atau pengakuan tentang penjelasan mengenai divinitas, alam gaib, termasuk kehidupan, kematian, surge, neraka dan lainnya. Kedua, praktek keagamaan (religious practice) atau dimensi ritualistic (ritualistic dimension). Dimensi ini berkaitan dengan aspek peribadatan termasuk upacara-upacara peribadatan yang dilakukan pemeluknya dalam rangka mnyembahTuhan yang diyakini. Dengan demikian dimensi ini lebih merupakan manifestasi keyakinan yang dimiliki pemeluknya. Ketiga, adalah pengalaman beragama (religious experience dimension) yang meliputi perasaan dan persepsi tentang proses kontaknya dengan apa yang diyakini sebagai sebagai "the ultimate reality", "devine power" "atau Sang Ilahi, serta penghayatan terhadap hal-hal yang relijius. Ketika mendengar bacaan al Qur'an,

\footnotetext{
${ }^{3}$ Emile Durkheim. 1997. The Elementary Form of the Religious Life, Free Press, New York, hal.439

4 Keith Roberts. 1984. Religious in Sociological Perspective, Homewood, Illinois, hal 96-104
}

misalnyamaka terjadi proses internalisasi sehingga membentukstruktur psikis (perasaan) tertentu sebagai pengalaman beragama.

\section{Paham Keagamaan}

Bentuk implementasi faham keagamaan adalah corak berfikir keagamaan, yaitu suatu bentuk, pola, model atau struktur berfikir seseorang yang dihasilkan dari proses belajar berlandaskan nilai-nilai yang diyakini kebenarannya sehingga pemikiran tersebut menjadi landasan untuk beraktivitas. Bentuk berfikir keagamaan, menurut Azyumardi Azra dapat dikelompokan menjadi tiga tipe, yaitu: a) Eksklusivisme ekstrim adalah jenis eksklusivisme yang sangat tertutup, dikotomi (benar-salah), dan radikal. Kelompok ini hanya membenarkan mazhabnya sendiri dengan serta merta menyalahkan, menyesatkan, dan mengkafirkan mazhab lain. b) Inklusifisme, adalah liberalisme moderat, plus keyakinan adanya sejumlah non muslim yang bisa selamat (masuk surga) karena beriman kepada Allah, kepada hari akhir dan beramal saleh. Kelompok ini memandang siapapun dapat masuk surga karena memiliki keyakinan kepada Allah dan percaya kepada hari akhir dan beramal saleh. 3) Liberalisme ekstrim adalah kelompok yang tidak membeda-bedakan lagi agama. Menurut kelompok ini, semua agama, terutama agamaagama besar, pada hakikatnya adalah Islam. Karena itu, semua agama karena sama-sama Islam adalah benar. Yang membedakan antara agama Islam dengan agama lainnya hanyalah dalam segi kualitasnya. ${ }^{5}$

\section{Metodologi Penelitian}

Jenis penelitian ini adalah kualitatif. Penelitian dilakukan di Universitas Pasundan Bandung dengan pertimbangan perguruan tinggi tersebut merupakan universitas pendidikan dan non Kependidikan. Universitas

${ }^{5}$ Azyumardi Azra. 1998. Konflik Baru Antar Peradaban: Globalisasi, Radikalisme dan Pluralitas, Penerbit: Raja Grafindo Persada, Jakarta, hal. 224 
ini memiliki dinamika aktifis ke-Islam-an dan pengaruhnya pada tingkat lokal dan nasional serta dinamika politik lokal yang berkembang terutama menyangkut isu isu radikalisme keagamaan maupun konflik agama.

Pengumpulan data dilakukan pada bulan Juni 2013 melalui pengamatan, studi dokumentasi dan wawancara. Hasil pengamatan dan wawancara mendalam direkam dan dicatat secara sistematis. Selanjutnya dilakukan pengklasifikasian atau pengkategorian data tentang kebijakan pendidikan agama dan proses pembelajaran. Visi dan misi Unpas dianalisa ada-tidaknya kaitan antara paham keagamaan para dosen dan proses pembelajaran mata kuliah agama dengan penerapan nilai nilai keagamaan.

\section{HASIL DAN PEMBAHASAN}

\section{Profil Universitas Pasundan (Unpas)}

Universitas Pasundan berdiri pada 14 Nopember 1960. Kehadiran dan pengembangan Universitas ini tidak bisa dilepaskan dari tujuan dan cita-cita organisasi Paguyuban Pasundan yang lahir pada 1914. Organisasi inilah yang awal mula membidani kelahiran universitas itu sebagai pengejawantahan pengabdian Paguyuban Pasundan dalam ikut serta mencerdaskan kehidupan dan kesejahteraan bangsa Indonesia. ${ }^{6}$

Pada awal berdirinya, ada dua fakultas yang mendukung kehadiran Unpas, yaitu Fakultas Hukum (FH) dan Fakultas Ilmu Sosial dan Ilmu Politik (FISIP). Di Fakultas Hukum ada dua jurusan: (1) Hukum Perdata dan (2) Hukum Pidana. Adapun di Fakultas Sosial dan Ilmu Politik ada beberapa jurusan: (1) Administrasi Negara; (2) Kesejahteraan Sosial; dan (3) Hubungan Internasional. Karena meningkatnya kebutuhan dan tuntutan masyarakat, maka di dua fakultas ini dibuka jurusan baru; yaitu

${ }^{6}$ Lihat Buku Panduan Mahasiswa Tahun Akademik 2013/2014", Penerbit: Universitas Pasundan, hal. 3; lihat pula profil Pasundan University, hal. 6.
Jurusan Administrasi Niaga dan Jurusan Ilmu Komunikasi untuk FISIP serta Jurusan Hukum Tata Negara untuk Fakultas Hukum. Namun, sejak 1993 berdasarkan keputusan Konsorsium Ilmu Hukum jurusan tersebut diubah menjadi bagian. $^{?}$

Selanjutnya, pada 1961 Unpas membuka fakultas baru; yaitu Fakultas Teknologi (FT) dengan jurusan Teknologi Makanan dan Teknik Produksi. Namun, kemudian jurusan Teknologi Makanan berubah menjadi Jurusan Teknologi Pangan, dan Jurusan Teknik Produksi berubah menjadi Jurusan Teknik Industri.

Sepuluh tahun kemudian (tepatnya pertengahan dasawarsa 70-an), Unpas membuka kembali fakultas baru; yaitu Fakultas Ekonomi (FE) dan Fakultas Keguruan dan Ilmu Pendidikan (FKIP). Hingga saat ini Fakultas Ekonomi mempunyai tiga jurusan: (1) Jurusan Manajemen, (2) Akuntansi, dan (3) Jurusan Ilmu Ekonomi Studi Pembangunan. Sedangkan Fakultas Keguruan dan Ilmu Pendidikan mempunyai lima jurusan: (1) PPKN, (2) Pendidikan Ekonomi Akuntansi, (3) Pendidikan Bahasa, Sastra Indonesia dan Daerah, (4) Pendidikan Matematika, dan (5) Pendidikan Biologi. ${ }^{8}$

Seiring dengan berjalannya waktu, Universitas Pasundan mengalami kemajuan, terutama dalam pengembangan Fakultas dan Jurusan/Program Studi/Program Kekhususan. Hal ini terlihat pada gambaran berikut: " pertama, Fakultas Hukum, dengan Program Ilmu Hukum terdiri dari Program Kekhususan Kepentingan Individu dan Masyarakat, Penegakan Hukum Pidana, Kebijakan Hukum dan Politik, Hukum Ekonomi Internasional. Kedua, Fakultas Ilmu Sosial dan Ilmu Politik, terdiri atas Jurusan Administrasi Negara, Kesejahteraan Sosial, hubungan Internasional, Administrasi Niaga, dan Ilmu Komunikasi. Ketiga, Fakultas Teknik, terdiri atas Jurusan

\footnotetext{
7 "Buku Panduan Mahasiswa ... ...", hal. 3.

8 "Buku Panduan Mahasiswa ... ...", hal. 3.

${ }^{9}$ Dikutip dari "Buku Panduan Mahasiswa ... ...", hal. 3-4.
} 
Teknologi Pangan, Teknik Industri, Teknik Mesin, Teknik Informatika, Teknik Lingkungan dan Teknik Planologi (Perencanaan Wilayah Kota). Keempat, Fakultas Ekonomi, terdiri dari Jurusan Manajemen, Akuntansi, dan Ekonomi Pembangunan. Kelima, Fakultas Keguruan dan Ilmu Pendidikan, terdiri atas Jurusan Pendidikan Pancasila dan Kewarganegaraan, Pendidikan Ekonomi Akuntansi, Pendidikan Bahasa, Sastra Indonesia dan Daerah, Pendidikan Matematika, Pendidikan Biologi dan Pendidikan Guru Sekolah Dasar. Keenam, Fakultas Ilmu Seni dan Sastra, terdiri atas Jurusan Desain Komunikasi Visual, Fotografi dan Film, Seni Musik, dan Sastra Inggris. Ketujuh, Fakultas Pascasarjana, terdiri atas Program Magister Ilmu Administrasi, Program Magister Manajemen, Program Magister Teknik dan Manajemen Industri, Program Magister Hukum, dan Program Magister Teknologi Pangan, Program Magister Pendidikan Matematika dan Program Magister Teknik Mesin. Selain Program Magister, juga dikembangkan Program Doktor, yang terdiri dari Program Doktor Ilmu Manajemen dan Program Doktor Ilmu Sosial/BKU Ilmu Administrasi Publik dan Program Doktor Ilmu Hukum.

Visi Universitas Pasundan adalah menjadi komunitas akademik peringkat internasioal yang mengusung nilai sunda dan Islam. ${ }_{10}$ Misi Universitas Pasundan adalah: a) menyelenggarakan pendidikan tinggi bertaraf internasional, b) mewujudkan penelitian bertaraf internasional, c) menyelenggarakan pengabdian kepada masyarakat untuk meningkatkan martabat manusia, d) menjaga, memelihara dan mengembangkan budaya Sunda, dan e) menjaga, memelihara dan mengembangkan Syi'ar Islam. ${ }^{11}$

\section{Paham Keagamaan Dosen Agama PAI}

${ }^{10}$ Dikutip dari "Buku Panduan Mahasiswa ... ...", hal. 7; lihat pula profil Pasundan Unversity, hal. 7.

${ }^{11}$ Dikutip dari "Buku Panduan Mahasiswa ... ...", hal 7; lihat pula profil Pasundan University, hal. 7.
Dosen agama PAI di Unpas berjumlah sekitar 14 orang. Dari jumlah ini hanya 9 orang yang termasuk dosen tetap (8 orang laki-laki dan 1 orang perempuan). Selebihnya dosen tidak tetap. Mereka mengajar di sejumlah fakultas, yaitu: (1) Fakultas Ilmu Sosial dan Ilmu Politik (FISIP); (2) Fakultas Ekonomi; (3) Fakultas Hukum; (4) Fakultas Teknik; (5) Fakultas Keguruan dan Ilmu Pendidikan; dan (6) Fakultas Ilmu Seni dan Sastra.

Latar belakang mereka tampaknya cukup beragam. Ada dari IAIN (sekarang UIN) Bandung, UNISBA (Tarbiyah), dan IKIP (sekarang UPI). Umumnya mereka lulusan Pendidikan Agama Islam. Namun, meskipun tidak dari IAIN/UIN yang penting mereka menguasai bahasa Arab. ${ }^{12}$

Di samping mengajar, dosen agama PAI juga aktif di berbagai organisasi keagamaan di tingkat provinsi. Misalnya, mereka aktif di NU, Muhammadiyah, dan GP Anshor. Mereka yang aktif di organisasi keagamaan tersebut juga menularkan ide-idenya kepada mahasiswa pada saat perkuliahan Pendidikan Agama Islam. ${ }^{13}$ Namun, ada juga di antara mereka yang memiliki pondok (kecil), yang ada kegiatan belajar mengajar. ${ }^{14}$

Salah seorang informan mengatakan bahwa latar belakang dosen agama PAI memengaruhi pemikiran/faham keagamaan mereka, termasuk latar belakang keluarga/ orang tua mereka. Tidak hanya itu, karakter pribadi masing-masing juga turut memengaruhi pemikiran keagamaan mereka.

${ }^{12}$ Wawancara dengan aktivis dakwah kampus, 177-2013; wawancara dengan Wakil Rektor I, 19-7-2013; wawancara dengan koordinator dosen agama PAI, 22-72013. Penting dicatat, berdasarkan wawancara informan umumnya menyatakan bahwa dosen agama PAI lulusan Pendidikan Agama Islam. Meskipun demikian, dilihat dari curriculum vitae responden memang mereka berasal dari IAIN/UIN, namun fakultas/jurusan/program yang diambil beragam. Ada yang lulusan Fakultas Ushuluddin, Perdata Pidana Islam, Dakwah, dan Syari'ah (Hukum Islam) Jurusan Tafsir Hadist

${ }^{13}$ Wawancara dengan koordinator dosen PAI, 22-72013. 2013. 
Namun, bagaimanapun, sebagaimana tertera dalam visi Unpas, dosen agama PAI dituntut untuk selain membudayakan budaya Sunda juga menumbuhkan syi'ar Islam. ${ }^{15}$

\section{Relasi Agama dan Negara}

Perbincangan tentang relasi agama dan negara diawali dengan diskusi mengenai sistem pemerintahan dengan Pancasila dan UUD 45 sebagai dasar negara dan sistem pemilu dalam memilih presiden dan anggota parlemen. Seorang informan berpandangan bahwa Pancasila dan UUD 45 tidak ada masalah sebagai dasar negara dan sistem pemilu dalam memilih presiden dan anggota parlemen. Namun, yang bermasalah justru sekarang ini adalah pemimpin-pemimpin yang ada di pemerintahan. ${ }^{16}$ Informan lain menyatakan bahwa secara umum pemerintah sudah mengayomi, karena Pancasila mengakomodir keberagaman, dan juga menghargai perbedaan. ${ }^{17}$ Lagi pula falsafah negara (Pancasila) itu lahir dari kompromi dari berbagai pihak dan aliran, yang di dalamnya mengajarkan sikap toleran. ${ }^{18}$

Selanjutnya, mengenai penegakan hukum Islam di Indonesia seorang informan mengatakan penegakan hukum Islam itu sesuatu hal yang bagus, tapi apakah sudah siap umat Islam di Indonesia. Ini tergantung pada pribadi masing-masing. Apakah Hukum Islam bisa jadi acuan? Menurutnya, karena hukum Allah itu mutlak dari segi penerapannya maka untuk saat ini masih tidak memungkinkan. ${ }^{19}$ Hal ini selaras dengan pandangan informan lain bahwa negara kita mayoritas muslim tapi bukan negara Islam dan tentu saja penegakan hukum pada aturan Islam agak sulit

\footnotetext{
${ }^{15}$ Wawancara dengan Wakil Rektor I, 19-7-2013.

${ }^{16}$ Wawancara dengan aktivis dakwah kampus, 17-72013.

${ }^{17}$ Wawancara dengan Wakil Rektor I, 19-7-2013. 2013.

${ }^{18}$ Wawancara dengan koordinator dosen PAI, 22-72013.
}

diberlakukan. $^{20}$ Memang, seperti dikatakan salah seorang informan, tidak ada umat Islam yang tidak setuju dengan hukum Islam. Hanya persoalannya, apakah hukum Islam itu bisa diterapkan? Yang masih mengkhawatirkan adalah pemahaman umat Islam yang masih parsial dan dikotomis terhadap ajaran Islam, dan belum beraklhak sebaimana ajaran Islam sehingga bercitra buruk atau tidak maslahat terhadap umat dan ajaran Islam. Menurutnya, apa artinya nama Islam kalau di dalamnya belum tercermin sifat seorang muslim. ${ }^{21}$

Salah seorang informan mengatakan bahwa sistem demokrasi yang sekarang ini kita kembangkan lebih mengembangkan konsep Barat. Padahal berbeda dengan budaya kita, kita seharusnya menerapkan musyawarah. Dan, menurut konsep Islam itu menghargai orang lain. ${ }^{22}$ Ini sejalan dengan informan lain yang mengatakan bahwa lebih pas dengan musyawarah mufakat sebagaimana tertera dalam sila keempat. Menurutnya, demokrasi sekarang mahal, setiap pilkada berapa ratus kalilipat uang dikeluarkan, padahal itu lebih bermanfaat dipakai buat rakyat. Jadi, untuk sekarang Indonesia belum siap berdemokrasi. ${ }^{23} 26$

Untuk melaksanakan hukum Islam para informan tampaknya cenderung berpendapat tidak perlu dibentuk negara Islam. Sebagaimana dikemukakan salah seorang informan bahwa negara Islam tidak perlu dibentuk, yang penting nilai-nilai Islam diterapkan. Namun, seringkali nilai-nilai Islam menjadi dangkal karena penafsiran, padahal penafsiran itu selalu berkembang. Dia mengibaratkan suatu saat misalnya kita melewati kebun jagung, tapi di dalamnnya rumput, apakah masih bisa dibilang kebun jagung. Jika memang ada buah jagung sudah pasti jadi kebun jagung. Itu yang

\footnotetext{
${ }^{20}$ Wawancara dengan Wakil Rektor I, 19-7-2013.

${ }^{21}$ Wawancara dengan koordinator dosen PAI, 22-7-

${ }^{22}$ Wawancara dengan Wakil Rektor I, 19-7-2013.

${ }^{23} 26$ Wawancara dengan koordinator dosen PAI, 22-
} 2013. 7-2013. 
jadi persoalan sekarang ini terkait dengan pendangkalan nilai-nila tersebut. ${ }^{24} 27$

Sejalan dengan itu, informan lain juga mengatakan bahwa sebagai warga negara tentu saja akan mengikuti pemerintah, rasanya sulit untuk membentuk negara Islam. Oleh karena itu, yang penting bagaimana caranya melaksanakan syariat Islam. Bagaimana meningkatkan kualitas orangnya dalam konteks Islam, itu jauh lebih baik. ${ }^{25} 28$ Yang penting --menurut salah seorang informan -- aturan-aturan yang dikeluarkan negara mengacu pada Al-Qur'an dan Hadits. Namun, dalam kasus undang-undang pornografi misalnya-- kenapa susah disahkan? Padahal sudah jelas dalam Al-Qur'an kalau itu haram. Dalam konteks agama, seharusnya itu segera disahkan. Tapi banyak pertimbangan dari pemerintah karena negara dipimpin oleh orang Islam yang kurang memiliki spirit ke Islaman yang "Universal" tentang baik dan buruk. ${ }^{26} 29$

Adapun mengenai hubungan agama dan negara, seorang informan menegaskan bahwa keterlibatan negara sangat diperlukan dalam urusan agama, karena negara memiliki wewenang dan kekuasaan. Setiap manusia punya perbedaan dan pasti ada konflik, jika bukan negara yang menertibkan siapa lagi. ${ }^{27} 30$ Sebab, negaralah yang punya otoritas absah untuk itu. Hal senada dikemukakan informan lain. Menurutnya, masyarakat harus dilindungi oleh pemerintah, pemerintah yang harus mengatur ketertiban. Jika dibiarkan tanpa ada keterlibatan pemerintah itu akan chaos. Jadi, tugas pemerintah ialah bagaimana membina kerukunan supaya keyakinan yang telah diakui bisa berdampingan secara baik. Suatu keyakinan yang dilindungi oleh negara. Karena adanya ajaran tertentu yang berbeda

${ }^{24} 27$ Wawancara dengan koordinator dosen PAI, 227-2013.

${ }^{25} 28$ Wawancara dengan Wakil Rektor I, 19-7-2013. 7-2013.

${ }^{26} 29$ Wawancara dengan aktivis dakwah kampus, 177-2013.

${ }^{27} 30$ Wawancara dengan aktivis dakwah kampus, 17- di masyarakat umumnya akan menimbulkan konfilk. ${ }^{28} 31$ Di situlah pemerintah harus berperan. Jika pemerintah terlibat dalam menertibkan masyarakat, maka tidak perlu ada FPI --misalnya-- karena negara punya otoritas. Lagi pula, perorangan atau kelompok tidak punya hak untuk melakukan penertiban. Cukup negara yang melakukan hal itu. Oleh karena itu, pemerintah harus bersikap tegas. ${ }^{29} 32$

\section{Hak Azazi Manusia (HAM)}

Terkait dengan HAM, seorang informan mengatakan kita terkadang berpikir tentang hak kita; padahal orang lain terdzalimi. HAM yang ada sekarang lebih mengutamakan hak daripada kewajiban. Oleh karena itu, HAM di situ secara pribadi bisa ada manfaat dan juga ada madharat. ${ }^{30} 33$ Sebaliknya, dalam Islam, selain memperhatikan hakjuga mengutamakan kewajiban. Informan lain mengutarakan, HAM yang ada sekarang lebih banyak dari Barat, sehingga agak berbenturan sedikit dengan budaya kita. Memang Amerika menjunjung tinggi HAM, tapi pada suatu kepentingan mereka juga kadang-kadang menghilangkan HAM itu sendiri demi kepentingannya. Suatu kenyataan bahwa konsep HAM itu dikembangkan ke kita dari Barat, pada saat yang sama Amerika melakukan standar ganda terkait dengan kepentingannya. Dalam konsep Islam HAM itu fitrah dan kita kembali ke AlQur'an dan Hadist. Demikianlah, misalnya, Rasulullah tidak memaksa semua orang untuk masuk Islam, karena ini bagian dari HAM. ${ }^{31} 34$

Sehubungan dengan seseorang berpindah agama atas naman HAM, seorang informan mengemukakan bahwa dalam Islam tidak boleh, bahkan dosa. Memang itu urusan pribadi, tapi tetap dosa. Maka dari itu, “... saya itu kalau

\footnotetext{
${ }^{28} 31$ Wawancara dengan Wakil Rektor I, 19-7-2013.

${ }^{29} 32$ Wawancara dengan koordinator dosen PAI, 227-2013.

${ }^{30} 33$ Wawancara dengan aktivis dakwah kampus, 177-2013.

${ }^{31} 34$ Wawancara dengan Wakil Rektor I, 19-7-2013.
} 
ngajar sering bilang anda harus yakin dengan pilihan agama yang akan menyelamatkan anda dan keluarga nantinya. Bukan karena orang tua atau HAM, jadilah agama itu kebutuhan untuk diri sendiri", kata seorang informan. ${ }^{32} 35$ Lebih jauh informan lain menegaskan bahwa pindah agama itu haram. Tapi untuk bersosial tidak masalah, meskipun dalam keyakinan beda. Oleh sebab itu, dalam bermasyarakat kita tidak boleh menyakiti non muslim. Meskipun demikian, bagi informan yang lain agama itu berdasarkan iman, terserah keyakinan masingmasing, biarkan Allah yanag memberikan hidayah untuk mereka. ${ }^{33} 36$

Soal kebebasan beragama saat ini, seorang informan mengatakan bagus tapi pelaksanaannya yang kurang. Dibandingkan dengan negara lain, kita jauh ketinggalan. Masalahnya adalah soal pembinaan yang harus dilakukan di lapangan. Misalnya, terjadi perkelahian remaja beda agama bisa muncul di permukaan dan menjadi masalah besar, sampai bisa perang 1 desa. ${ }^{34} 37$ Pandangan serupa dikemukakan informan lain. Menurutnya, kebebasan beragama saat ini bagus karena semua pihak bisa berekspersi, semuanya diberikan haknya oleh pemerintah. Tapi biasanya yang minoritas merasa dikucilkan, padahal dari kita tidak ada masalah. Dia menegaskan agama Islam kalau mayoritas mereka aman. ${ }^{35} 38$ Informan yang lain mengatakan kondisi kebebasan beragama “... kalau bebas ya bebas, kalau di pemerintah sudah lumayan bagus. Persoalan umat Islam tentang fatwa MUI taati saja, dan bila ada masalah diselesaikan saja pada tingkat pusat dan kota. Tapi jangan memburukkan atau menjelekan agama lain". 3639

3235 Wawancara dengan koordinator dosen PAI, 227-2013.

${ }^{33} 36$ Wawancara dengan aktivis dakwah kampus, 177-2013.

3437 Wawancara dengan Wakil Rektor I, 19-7-2013.

${ }^{35} 38$ Wawancara dengan koordinator dosen PAI, 227-2013.

${ }^{36} 39$ Wawancara dengan aktivis dakwah kampus, 177-2013.

\section{Toleransi}

Ketika membicarakan persoalan pembangunan rumah ibadah antara umat beragama, seorang informan mengatakan tidak masalah asal di suatu wilayah (A misalnya) ada orang non muslim dan ingin membangun gereja. Kita tidak bisa melarang. Sebab, dalam Islam bahkan orang musyrik pun dilindungi. ${ }^{37} 40$ Menurut seorang informan, jika ada rumah yang dipakai untuk beribadah harus diakomodir biar tidak ada salah faham, dan tidak boleh ada yang saling menghalangi di antara mereka. ${ }^{38} 41$ Namun, bagi informan lain, sebaiknya mengikuti aturan pemerintah, dengan jarak sekian. Sebab, beberapa kejadian yang menyebabkan rumah ibadah dilempari karena tidak melihat aturan lingkungan dan tidak memperhatikan jumlah pemeluknya. Di sinilah pemerintah harus tegas, pemerintah harus langsung membuat perencanaan. Paling tidak pemerintah menyediakan lahan untuk ibadah masing-masing. Lebih jauh, dia mengatakan "... sebenarnya yang harus banyak mengalah kita, kita harus punya sifat toleran, jadi dimanapun kalo mayoritas umat Islam agama manapun akan aman. Coba lihat yang lain kalau umat Islam yang minoritas sudah pasti tidak aman kayak di Ambon, jadi Islam itu rahmatan lil alamin". ${ }^{39} 42$

Jika ada pemeluk agama lain yang ingin mendirikan rumah ibadah di tengah-tengah mayoritas agama lain, menurut seorang informan tidak boleh dihalang-halangi, tapi harus memperhatikan lingkungan sekitarnya dan harus ditentukan tempatnya secara bermusyawarah..$^{40} 43$ Mereka harus ikut aturan. Hal ini bukan berarti pemerintah menyulitkan, karena aturan itu dibuat berdasarkan kajian. ${ }^{41} 44$ Namun, bagi informan lain, “... kalau

\footnotetext{
${ }^{37} 40$ Wawancara dengan aktivis dakwah kampus, 177-2013.

${ }^{38} 41$ Wawancara dengan Wakil Rektor I, 19-7-2013.

${ }^{39} 42$ Wawancara dengan koordinator dosen PAI, 227-2013.

${ }^{40} 43$ Wawancara dengan Wakil Rektor I, 19-7-2013.

${ }^{41} 44$ Wawancara dengan koordinator dosen PAI, 22-7-2013.
} 
pribadi, silahkan saja asal jangan mengganggu, maksudnya mengajak berdakwah, biasanya rumah ibadah seperti itu. Pusat dakwah pasti gereja juga akan seperti itu, kalau mereka bergerak ke orang muslim baru diberikan tindakan". ${ }^{42} 45$

Dalam kaitan inilah, peran pemerintah dalam mengatasi persoalan pembanguna rumah ibadah umat bergama cukup signifikan. Menurut seorang informan, pemerintah harus bisa mempertahankan kondisi yang baik dan melakukan komunikasi. Selama ini masyarakat merasa tidak diajak bicara, pada saat yang bersamaan harus menaati aturan yang ada. Oleh karena itu, pemerintah harus menjadi organizer yang betul-betul berfungsi menegakkan hukum ${ }^{43} 46$ dan dia punya hak untuk itu. ${ }^{44} 47$ Selain itu, pemerintah juga harus memberikan pemahaman kepada kelompok mayoritas agar tidak menindas yang minoritas. Dengan begitu, karena pemerintah menjadi penengah maka konflik tidak terjadi. ${ }^{45} 48$

\section{Kesetaraan Jender}

Diskusi tentang kesetaraan jender, ada dua hal pokok yang menjadi sorotan; yaitu soal kepemimpinan perempuan dalam politik/pemerintahan dan relasi lakilaki dan perempuan dalam rumah tangga, antara peran domestik dan luar. Mengenai kepemimpinan perempuan dalam politik/ pemerintahan, seorang informan mengatakan lebih baik laki-laki yang memimpin dalam pemerintahan, sedangkan perempuan itu untuk posisi wakilnya. ${ }^{46} 49$ Informan lain berpandangan bahwa perempuan cenderung menggunakan perasaaan. Karena itu, dalam

${ }^{42} 45$ Wawancara dengan aktivis dakwah kampus, 177-2013.

${ }^{43} 46$ Wawancara dengan Wakil Rektor I, 19-7-2013.

${ }^{44} 47$ Wawancara dengan koordinator dosen PAI, 227-2013.

${ }^{45} 48$ Wawancara dengan aktivis dakwah kampus, 177-2013. 7-2013.

${ }^{46} 49$ Wawancara dengan aktivis dakwah kampus, $17-$ pengambilan keputusan biasanya juga menggunakan perasaan. Dalam Islam, muslim laki-laki itu ditakdirkan menjadi seorang pemimpin. Sepanjang laki-laki masih ada maka yang menjadi pemimpin adalah lakilaki. Tapi, dalam pandangannya, seorang perempuan bisa saja menjadi pemimpin jika sudah tidak ada laki-laki cukup pantas menjadi pemimpin. Jadi, situasi dan kondisi yang ada menentukan apakah seorang perempuan bisa menjadi memimpin atau tidak. ${ }^{47} 50$ Pandangan ini selaras dengan informan yang lainnya yang menyatakan bahwa meskipun ada ayat "arrijalu qawwamuna 'alannisa" dan pada ayat lain "minhum ba'duhum fauqo ba'din" kepemimpinan perempuan bisa menjadi pengecualian kalau memang tidak ada lakilaki. ${ }^{48} 51$

Adapun menyangkut relasi laki-laki dan perempuan dalam rumah tangga, antara domestik dan luar, seorang informan mengatakan perempuan itu lebih baik menjalankan peran domestik dalam keluarga. Tapi, kalau punya ilmu dan ingin mengembangkannya di luar tidak dilarang, namun dalam batas-batas tertentu, misalnya mengajar. Dan, laki-laki tetap sebagai pemimpin. ${ }^{49} 52$ Peran seperti ini bisa dilakukan seorang perempuan karena Islam menjunjung tinggi mereka. Tapi, mereka sebagai seorang muslimah harus menjaga kehormatan keluarga ${ }^{50} 53$ Lagi-lagi peran ini bisa dijalankan sepanjang suami mengizinkan mereka untuk bekerja (menjalan peran di luar domestik). Jika suami tidak mengizinkan, maka seorang perempuan tidak diperkenankan menjalankan peran tersebut. ${ }^{51} 54$

\footnotetext{
4750 Wawancara dengan Wakil Rektor I, 19-7-2013.

${ }_{48}^{4} 51$ Wawancara dengan koordinator dosen PAI, 227-2013.

${ }^{49} 52$ Wawancara dengan koordintor dosen PAI, 227-2013.

${ }^{50} 53$ Wawancara dengan Wakil Rektor I, 19-7-2013.

${ }^{51} 54$ Wawancara dengan aktivis dakwah kampus, 177-2013.
} 


\section{Sistem Pengajaran PAI}

Pada bagian ini akan dibicarakan halhal mengenai silabus/kurikulum, fasilitas pengajaran, sistem pengajaran, dan sumber pengajaran.

\section{Silabus/Kurikulum}

Seorang informan mengatakan bahwa seluruh dosen PAI di Unpas menggunakan silabus/kurikulum yang dari Depag dan ditambahkan dengan muatan lokalnya. Misalnya pokok agama, aqidah, syariah, akhlak dan itu menjadi pengajaran yang pokok. ${ }^{52} 55$ Silabus ini penting karena menjadi acuan mengenai apa yang akan disampaikan dan siapa sasarannya/ tujuannya. Di samping itu, juga bagaimana evaluasinya, pertemuannya, dan apa referensinya. ${ }^{53} 56$

Salah seorang informan mengutarakan bahwa mata kuliah PAI ada 2 semester, semester 1 Islam, fikih dan lain-lain dan semester 2 dasar ilmu, teori dasar atau Islam untuk disiplin ilmu. ${ }^{54} 57$ Isi silabus PAI untuk semester I meliputi: (1) urgensi agama dalam kehidupan; (2) Khaliq (Pencipta) dan makhluq (alam semesta dan manusia); (3) dinul Islam; (4) sumber nilai ajaran Islam; (5) ibadah dan hikmahnya; (6) akhlak dan tasawuf; (7) sejarah peradaban dan pemikiran; (8) toleransi dalam Islam; (9) Islam dan kesundaan sebagai identitas Unpas; (10) Islam untuk disiplin ilmu (hukum dalam perspektif Islam, pendidikan dalam perspektif Islam, politik dalam perspektif Islam, ekonomi dalam perspektif Islam, teknologi dalam perspektif Islam, dan bahasa, sastra dan seni dalam persepktif Islam). Untuk isi silabus PAI semester 2 mencakup: (1) universalitas Islam dalam konteks Islam untuk Disiplin Ilmu (IDI); (2) ilmu pengetahuan dalam perspektif Islam; (3) alam, manusia dan Tuhan; (4) Islam

${ }^{52} 55$ Wawancara dengan coordinator dosen PAI, 227-2013.

${ }^{5} 56$ Wawancara dengan Wakil Rektor I, 19-7-2013. 7-2013. untuk disiplin ilmu (pendidikan, ekonomi, sosial politik, hukum, teknik, seni dan sastra); dan (5) kapita selekta (program studi).

Informan lain mengatakan sebelum mengikuti mata kuliah PAI diawali terlebih dahulu dengan mentoring yang melibatkan pengurus DKM. Tujuannya untuk mengetahui baca tulis al-Qur'an mahasiswa. Menurutnya, setelah dicek ternyata mahasiswa yang bisa baca al-Qur'an jauh dari yang diharapkan. Bahkan ada mahasiswa Islam tapi tidak bisa baca al-Qur'an. Setelah itu baru memasuki materi mengenai penguatan keyakinan mengenai tugas pokok manusia, soal keyakinan, muamalah, ekonomi Islam, dan lain-lain. ${ }^{55} 58$

Untuk isu-isu tentang HAM, gender, relasi agama dan negara, dan toleransi ada dalam muamalah karena itu menyangkut/ berhubungan dengan orang lain. ${ }^{56} 59$

\section{Fasilitas Pengajaran}

Untuk fasilitas pengajaran PAI, disediakan in fokus dan in-out di kelas, juga ada mentoring PAI seperti kuliah biasa tapi di outdoor. ${ }^{57} 60$ Ini biasanya dilakukan di masjid dan ditemani mentor, mahasiswa senior mereka. Menurut salah seorang informan, dengan mentoring itu mata kuliah tidak bertabrakan dan kalau di kelas tidak cukup waktu mengetes satu per satu mahasiswa. Meskipun yang mementor mahasiswa senior tapi diarahkan oleh para dosen per kelompok. Per kelompok terdiri dari 2 mentor dan 10 mahasisa serta wajib semua ikut. ${ }^{58} 61$

Seorang informan mengatakan fasilitas itu memang masih kurang memadai dan ini masih menjadi kendala. Tapi, setidaknya dengan fasilitas yang ada kita bisa melakukan syiar Islam dan membudayakan nilai Sunda. Meskipun demikian, sekarang sedang

\footnotetext{
5558 Wawancara dengan Wakil Rektor I, 19-7-2013.

5659 Wawancara dengan Wakil Rektor I, 19-7-2013. 7-2013.

${ }^{57} 60$ Wawancara dengan aktivis dakwah kampus, 17-

${ }^{58} 61$ Wawancara dengan koordinator dosen PAI, 227-2013.
} 
diperjuangkan untuk menambah fasilitas itu. ${ }^{59} 62$ Dan, penting dicatat, seperti dikatakan informan lain, mentoring itu memberikan peningkatan wawasan, tapi memang kendalanya waktu yang sangat kurang. ${ }^{60} 63$

\section{Sistem Pengajaran}

Model pembelajaran yang dilakukan para dosen dalam pengajaran PAI tampaknya beragam. Ada ceramah, diskusi, tanya jawab, dan membaca. Model membaca diterapkan dengan cara meminta mahasiswa membaca 1 bab dari suatu buku lalu membuat ringkasan. Atau mereka diminta membaca 10 menit lalu dibuka ruang diskusi. ${ }^{61} 64$ Informan lainnya mengatakan dosen PAI juga menggunakan pendekatan dua arah. Dosen memberikan teori lalu mahasiswa merespon sehingga terjadilah proses diskusi. Setelah itu, mahasiswa diberi tugas untuk menyusun artikel. ${ }^{62} 65$ Model dialogis ini memberikan ruang bagi mahasiswa untuk berani mengatasi masalah yang dihadapi. Juga punya keberanian mengungkapkan persoalan yang berkaitan dengan agama. ${ }^{63} 66$

Dengan model pembelajaran seperti itu, menurut seorang informan, mahasiswa bisa paham. Tapi dengan tugas penyusunan artikel akan kelihatan jika penyajiannya datar-datar saja maka kurang bagus. ${ }^{64} 67$ Bagi informan lainnya, itu semua tergantung pada bagaimana si pengajar yang mengajarkannya, karena sumber daya kita heterogen. Di situlah dibutuhkan proses pembelajaran yang baik. ${ }^{65} 68$ Lebih jauh, salah seorang informan mengatakan kemauan membaca atau minat baca kurang di kalangan mahasiswa. Padahal

\footnotetext{
${ }^{59} 62$ Wawancara dengan Wakil Rektor I, 19-7-2013.

${ }^{60} 63$ Wawancara dengan aktivis dakwah kampus, 17-

${ }^{61} 64$ Wawancara dengan koordinator dosen PAI, 22-

${ }^{62} 65$ Wawancara dengan aktivis dakwah kampus, 17-

${ }^{63} 66$ Wawancara dengan Wakil Rektor I, 19-7-2013.

${ }^{64} 67$ Wawancara dengan aktivis dakwah kampus, 17-

${ }^{65} 68$ Wawancara dengan Wakil Rektor I, 19-7-2013.
} 7-2013. 7-2013. 7-2013. 7-2013. dengan membaca diharapkan mereka terlatih untuk memberikan interpretasi. Karena itu, meskipun kita menggunakan study learning center dan juga pendekatan student oriented, dialog agak kurang berjalan karena kecenderungan mahasiswa sekarang pasif. ${ }^{66} 69$

Adapun partisipasi mahasiswa dalam perkuliahan PAI, menurut salah seorang informan, cukup banyak. Tapi ada beberapa mahasiswa yang kurang tingkat kehadirannya. Menurutnya, keikutsertaan mereka dalam perkuliahan menjadi wajar karena mereka mengejar nilai. Sedangkan untuk mentoring ada yang rajin dan juga ada yang malas ${ }^{67} 70$

Tingkat kehadiran itu dapat dilihat pada daftar hadir mahasiswa. Tampaknya ada Perbedaan mencolok antara mahasiswa Program Reguler dan Program Ekstensi dalam mengikuti perkuliahan PAI. Misalnya, pada Program Studi Akuntansi Kelas/ PAR: 10AKB/Reguler Pagi Semester: Ganjil, 2010/2011 dari 55 orang mahasiswa hampir semuanya mengikuti perkuliahan PAI selama 12 kali pertemuan. Sedangkan pada Program Ekstensi Program Studi Manajemen Kelas 10MJ1 Semester: Periode 1, 2011/2012 dari 44 orang mahasiswa hanya separuh yang selalu hadir dalam perkuliahan PAI selama 12 kali pertemuan. Kasus tersebut sebenarnya bersifat kasuistik, dan itu ditangani secara perkasus karena kehadiran tetap merupakan syarat mutlak kelulusan, oleh karena itu kasus yang belum tertangani padahal nilai harus segera diumumkan maka diputuskan tidak lulus. Yang bersangkutan masih dapat mengulang dengan disertakan surat bukti yang sah, seperti surat keterangan dokter atau surat tugas dari instansi.

Untuk dosen tamu terkait dengan perkuliahan PAI selama ini biasanya tidak secara khusus memberikan perkuliahan di kelas. Menurut seorang informan biasanya dosen

${ }^{66} 69$ Wawancara dengan koordinator dosen PAI, 227-2013. 7-2013.

\footnotetext{
${ }^{67} 70$ Wawancara dengan aktivis dakwah kampus, 17-
} 
tamu diundang dalam stadium general, misalnya dari Unpad. Materi yang diangkat menyangkut isu-isu aktual seperti tentang gerakan Islam (kasus Pesantren Al-Zaitun) atau aliran-aliran keagamaan. ${ }^{68} 71$

\section{Sumber Pengajaran}

Sumber pengajaran/literatur yang digunakan dalam PAI dibagi ke dalam beberapa kategori. Pertama, buku wajib/pegangan dan buku anjuran untuk mahasiswa. Kedua, buku Pendidikan Agama Islam untuk dosen. ${ }^{69} 72$ Yang pokoknya adalah buku "Afeksi Islam Menjelajahi Nilai-Rasa Transendental bersama Al-Qur'an", oleh Dr. H. Ali Anwar Yusuf, M.Si., dkk. ${ }^{70} 73$

Salah seorang informan mengatakan bahwa --sebagaimana daftar buku-buku di atas -- buku-buku atau literatur yang digunakan para dosen PAI memuat pandangan-pandangan yang kooperatif, saling menghargai, dan tidak fundamentalis. ${ }^{71} 76$ Kondisi ini tampaknya dipengaruhi oleh buku-buku yang sering dianjurkan untuk dibaca mahasiswa, misalnya buku Qurais Syihab, "Membumikan al-Qur'an", Endang Saefudin Ansori, "Wawasan Islam", Miftah Faridl, "Pokok-pokok Ajaran Islam", dan yang agak sedikit berat buku Nurcholis Madjid, "Doktrin dan Peradaban Islam".

\section{Evaluasi Sistem Pengajaran}

Seorang informan mengatakan evaluasi yang dilakukan dalam PAI menjadi pegangan bagi dosen apakah materi yang telah disampaikan sesuai atau tidak, apakah dapat dikuasai atau tidak. Juga ada evaluasi empiris (praktikum), misalnya, kalau ikut mentoring berapa kali hadir? Bagaimana kemampuan 7-2013.

${ }^{68} 71$ Wawancara dengan koordinator dosen PAI, 22-

${ }^{69} 72$ Wawancara dengan koordinator dosen PAI, 227-2013.

${ }^{70} 73$ Buku ini diterbitkan 2005 oleh tafakur berkhidmat untuk umat, Jalan Kiliningan II No. 9 Buahbatu-Bandung 40262.

${ }^{71} 76$ Wawancara dengan Wakil Rektor I, 19-7-2013. bacaannya, ada perubahan apa tidak? Selain itu, juga ada ujian tengah semester (UTS) dan ujian akhir semester (UAS). Ini semua Jadi komponen bahan evaluasi. ${ }^{72} 77$ Evaluasi ini, menurut informan lain, sesungguhnya bersifat reguler, ada penilain melalui jumlah kehadiran, tugas-tugas di kelas termasuk praktikum dengan bobot kehadiran, $10 \%$, tugas $15 \%$, UTS $35 \%$, dan UAS $40 \%$. Model evaluasi ini dilakukan dengan bentuk objective test dan ada juga dengan esai. ${ }^{73} 78$

Hasil evaluasi ini amat penting utuk melihat seberapa besar pengaruh materi yang telah disampaikan. Dengan evaluasi itu dapat dilihat bagaimana perbandingan antara input dan output bekerja. Disamping itu evaluasi itu berfungsi untuk perbaikan kurikulum. Biasanya 4 tahun sekali dilakukan perbaikan. ${ }^{74} 79$

Kriteria penilaian dalam evaluasi PAI meliputi komposisi ranah kognitif, ranah afektif dan ranah psikomotorik. Penggunaan kriteria ini bukan hal yang mudah. Seperti diakui seorang informan, mereka masih merasa kesulitan dalam merumuskan afeksi, karena sasarannya berkaitan dengan sikap. Kosa katanya agak sulit. Misalnya, sikap tolong menolong dan toleransi, pengujiannya tidak bisa sembarangan harus melalui pengamatan yang cermat. Apakah ada perubahan, yang tadinya tidak suka ke masjid tapi sekarang menjadi suka. Jadi, bukan hanya keterampilan dalam ibadahnya; karena itu psikomotor, tapi lebih ke kebiasaannya. Misalnya, kebiasaan tidak suka mengucapkan salam sekarang jadi suka. Hal ini merupakan bagian yang tersulit, yaitu merupakan dan mempraktekan proses internalisasi (dari pengetahuan agama menjadi sikap atau kepribadian beragama $)^{75} 80$

${ }^{72} 77$ Wawancara dengan Wakil Rektor I, 19-7-2013.

${ }^{73} 78$ Wawancara dengan koordinator dosen PAI, 227-2013.

${ }^{74} 79$ Wawancara dengan Wakil Rektor I, 19-7-2013.

${ }^{75} 80$ Wawancara dengan koordinator dosen PAI, 227-2013. 


\section{Sistem dan Rekruitmen Dosen PAI}

Terkait dengan mekanisme rekrutmen dosen PAI di Unpas, seorang informan mengatakan bahwa rekrutmen itu dilakukan melalui proses ujian. Kemudian sebelum mereka masuk jadi dosen, mereka mengabdi dulu sekitar 2 tahun. Setelah 2 tahun biasanya baru diangkat menjadi dosen. ${ }^{7} 82$ Menurut informan lain, ada dua mekanisme rekrutmen: Pertama, direkrut dari yayasan dan ini umumnya dosen tetap. Kedua, dari Luar Biasa (LB). Ini dilakukan karena tidak bisa ditangani oleh dosen tetap lantaran banyaknya mahasiswa. Ini semua dilakukan atas usulan fakultas ke pihak rektorat karena merekalah yang paling tahu akan kebutuhan dosen. Untuk saat ini, rekrutmen masih dengan cara nepotisme. Orang yang Kita kenal yang direkrut. Namun, tentu saja mereka mempunyai kompetensi. Oleh karena itu, tidak dipublikasikan; hanya disampaikan kepada penanggungjawab fakultas masing-masing. ${ }^{77} 83$

Syarat dalam rekrutmen dosen PAI, antara lain secara akademik harus punya prestasi yang bagus, harus S2, ada catatan baik di masyaratkat. Maka dari itu, ada cek di masyarakat. Rekrutmen ini tidak dilakukan per tahun tergantung kebutuhan. Untuk dosen PAI malah sudah terpenuhi, kebetulan ada 12 dosen LB (Luar Biasa) dan belum ada lagi yang diangkat. ${ }^{78} 84$ Menurut informan, yang paling sering adalah rekrutmen dosen LB untuk PAI, karena dosen tetap berdasarkan yayasan. ${ }^{79} 85$

Yang terlibat dalam rekrutmrn dosen PAI ialah dekan dan wakil dekan, baik untuk rekrutmen dosen LB maupun dosen tetap. Karena merekalah yang paling tahu di unit kerjanya masing-masing. Bahkan kini untuk dosen tetap harus bergelar doktor..$^{80} 86$ Tidak

${ }^{76} 82$ Wawancara dengan koordinator dosen PAI, 227-2013.

${ }^{77} 83$ Wawancara dengan Wakil Rektor I, 19-7-2013.

${ }^{78} 84$ Wawancara dengan koordinator dosen PAI, 227-2013; Wawancara dengan Wakil Rektor I, 19-7-2013.

${ }^{79} 85$ Wawancara dengan Wakil Rektor I, 19-7-2013.

${ }^{80} 86$ Wawancara dengan Wakil Rektor I, 19-7-2013. hanya itu, rektor dan yayasan juga terlibat. Dalam artian, dekan mengajukan ke rektor, tapi tetap ada keterlibatan dari yayasan. ${ }^{81} 87$

Adapun mekanisme pengambilan keputusan dalam penentuan dosen PAI berada pada Paguyuban Pasundan karena keputusan tertinggi ada situ. Memang usulan awal dari prodi kemudian ke fakultas baru masuk ke UNPAS lalu ke yayasan pendidikan tinggi. Terakhir, ke Paguyuban Pasundan. Namun, untuk dokumen dosen LB selesai di tingkat fakultas. ${ }^{82} 88$

\section{P EN U T U P}

Darideskripsi mengenaipaham keagamaan dosen PAI tentang relasi agama dan negara, HAM, toleransi, dan kesetaraan gender dapat disimpulkan dan direkomendasikan sebagai berikut:

\section{Kesimpulan}

Pertama, terkait dengan relasi agama dan negara. Para informan yang diwawancarai dalam penelitian ini tampaknya tidak mempersoalkan Pancasila dan UUD 45 sebagai dasar negara dan sistem pemilu dalam memilih presiden dan anggota parlemen. Karena Pancasila dan UUD 45 dapat memayungi dan menjadi landasan bagi hidup berbangsa dan bernegara. Bahkan dalam pandangan informan Pancasila itu mengandung nilai-nilai Islam. Karena itu, penegakan hukum Islam di Indonesia sepanjang tidak bertentangan dengan Pancasila tidak jadi soal. Persoalannya, apakah pribadi-pribadi Muslim sudah siap menegakkan hukum Islam? Dalam konteks ini, untuk melaksanakan hukum Islam tidak perlu dibentuk negara Islam karena akan berbenturan dengan konstitusi. Dalam pandangan informan, yang terpenting saat ini adalah bagaimana menanamkan nilai-nilai 7-2013.

${ }^{81} 87$ Wawancara dengan koordinator dosen PAI, 22${ }^{82} 88$ Wawancara dengan Wakil Rektor I, 19-7-2013. 
Islam ke dalam pribadi-pribadi muslim. Ini yang harus selalu dilakukan ketimbang sibuk dengan wacana negara Islam. Sistem demokrasi yang kita bangun sekarang ini terlalu berorientasi Barat. Sebetulnya tidak sesuai dengan budaya kita. Karena itu, belum pas buat umat Islam Indonesia. Yang ideal dalam pandangan informan ialah sistem demokrasi yang berdasarkan pada musyawarah-mufakat karena ini sesuai dengan budaya bangsa. Karena itulah, dalam kaitannya dengan peran negara para informan memiliki kesamaan pandangan bahwa negara harus terlibat dalam urusan agama dalam rangka menciptakan ketertiban agar tidak terjadi disharmoni dalam hubungan antar umat beragama. Bagi mereka hanya negara yang memiliki otoritas untuk melakukan penertiban bila terjadi persoalan terkait dengan hubungan antar umat beragama. Pada sudut inilah, dapat dikatakan bahwa pandangan para informan cenderung moderat dalam menyikapi soal relasi agama dan negara.

Kedua, terkait dengan HAM. Dalam pandangan informan, konsep HAM yang selama ini berkembang berasal dari Barat yang terlalu mengutamakan hak. Karena itu, tak heran, kebanyakan orang dewasa ini lebih menuntut haknya dan melupakan kewajibannya. Konsepsi HAM dalam Islam, menyeimbangkan antara hak dan kewajiban. Karena itu, tidak semata-mata menuntut hak tetapi juga harus memperhatikan kewajibannya. Selanjutnya, soal berpindah agama atas nama HAM, para informan berdasarkan keyakinan agamanyatidak diperbolehkan. Bahkan jika itu dilakukan seseorang akan mendapat dosa dari Tuhan. Dalam konteks hubungan sosial, pindah agama itu absah-absah saja. Namun, dalam konteks keimanan tetap tidak diperbolehkan. Mengenai kebebasan beragama di Indonesia para informan berpandangan bahwa hal itu sudah berjalan dengan bagus. Namun, kelemahannya di tingkat lapangan masih ada. Karena itu, perlu dilakukan pembinaan terusmenerus di tingkat lapangan. Pada sisi ini, para informan cenderung bersikap moderat dalam menanggapi masalah HAM.

Ketiga, terkait dengan toleransi. Sikap para informan hampir sama dalam menanggapi persoalan pembangungan rumah ibadah antara umat beragama. Mereka berpandangan pembangungan itu boleh-boleh saja asal sesuai dengan aturan yang ada. Karena itu, kelompok minoritas membangun rumah ibadah di tengah-tengah kelompok mayoritas tidak menjadi masalah jika hal itu memang sesuai dengan tuntutan umatnya dan tidak melanggar aturan yang ada mengenai pendirian rumah ibadah serta tidak mengganggu lingkungan sekitarnya. Dalam pandangan para informan acapkali terjadi konflik terkait dengan pendirian rumah ibadah karena tidak sesuai dengan aturan yang ada. Bahkan terkadang tidak sejalan dengan peruntukannya. Di tengah situasi itu, dalam pandangan para informan pemerintah harus berperan sebagai mediator dan fasilitator dalam penyelesaian persoalan pembangunan rumah ibadah itu. Pemerintah harus memberikan pemahaman kepada mereka mengenai atura-aturan pembangunan rumah ibadah agar tidak terjadi konflik lagi di kemudian hari. Pada ranah pemikiran ini, para informan cenderung bersikap moderat dalam merespon persoalan pembuangan rumah ibadah antara umat beragama.

Keempat, terkait dengan kesetaraan gender. Para informan dalam penelitian ini cenderung berpandangan bahwa kepemimpinan dalam politik/pemerintahan harus dipegang oleh laki-laki, bukan perempuan. Karena laki-laki ditakdirkan untuk menjadi pemimpin di muka bumi. Meskipun demikian, dalam pandangan informan seorang perempuan boleh saja manjadi pemimpin jika memang tidak ada lakilaki yang mampu untuk menjadi pemimpin. Di sini sifatnya kondisional untuk perempuan, apakah boleh memimpin atau tidak. Untuk peran seorang perempuan di luar rumah atau peran domestik, para informan berpendapat sebaikanya seorang perempuan menjalankan peran domestik. Karena seorang perempuan 
sangat diharapkan kehadirannya dalam mendidik anak-anak mereka. Namun demikian, para informan tidak menyangkal jika seorang perempuan mau bekerja asalkan mendapat izin suami. Pada konteks ini, para informan juga bersikap moderat dalam menyikapi persoalan kesetaraan gender.

\section{Rekomendasi}

Melihat kondisi tersebut diatas ke depannya dapat direkomendasikan:

Pertama, terkait dengan isu HAM, gender, dan relasi agama dan Negara, masuk ke dalam materi pembahasan PAI. Karena isu-isu ini selalu menjadi perdebatan akhir-akhir ini dalam konteks hidup berbangsa dan bernegara.

Kedua, untuk menjaga akuntabilitas publik sebaiknya ke depan rekrutmen dosen PAI diadakan secara terbuka dan transparan sehingga dapat diakses oleh siapa pun yang ingin mendaftar sebagai calon dosen PAI.

\section{SUMBER BACAAN}

Dr. Alwi Shihab,. 1998. Islam Inklusif (Menuju Sikap terbuka Dalam Beragama), Penerbit: Mizan, Bandung,, Cetakan III

Azyumardi Azra. 1998. Konflik Baru Antar Peradaban: Globalisasi, Radikalisme dan Pluralitas, Penerbit: Raja Grafindo Persada, Jakarta

Azra Azyumardi. 2000. Demokrasi, Hak Asasi Manusia, dan Masyarakat Madani, Jakarta: TIM ICCE UIN Syarif Hidayatullah Jakarta.

Bafadal AR Fadhal. 2005. Drs. Pengalaman Agama di Kalangan Pemuda, Jakarta: Sekjen Departemen Agama RI

Buku Panduan Mahasiswa Tahun Akademik 2013/2014. 2013. Penerbit: Universitas Pasundan

Dahl, Robert A., Perihal Demokrasi, Jakarta: Yayasan Obor Indonesia, 2001

Emile Durkheim. 1997. The Elementary Form of the Religious Life, Free Press, New York

Esposito, John L.dan John O. Voll, 1996. Islam and Democracy, New York: Oxford University Press
Farha, Ciciek, 2005. Jangan Ada Lagi Kekerasan dalam Rumah Tangga. Jakarta: PT. Gramedia Pustaka Utama.

Keith Roberts. 1984. Religious in Sociological Perspective, Homewood, Illinois

Mujani, Saiful., 2007, Muslim Demokrat, Jakarta: PT. Gramedia Pustaka Utama, IKAPI, ISBN13: 978-979-22-2749-9

Yayasan Pendidikan Tinggi (YPT) Pasundan. 2009. Panduan Pelaksanaan Mata Kuliah Wajib Pasundan (MKWP) Pendidikan Agama Islam "Islam Untuk Disiplin Ilmu”. Penerbit: Karya Mulya Utami Print, YPT Pasundan. 